\title{
Understanding persecution in Matthew 10:16-23 and its implication in the Nigerian church
}

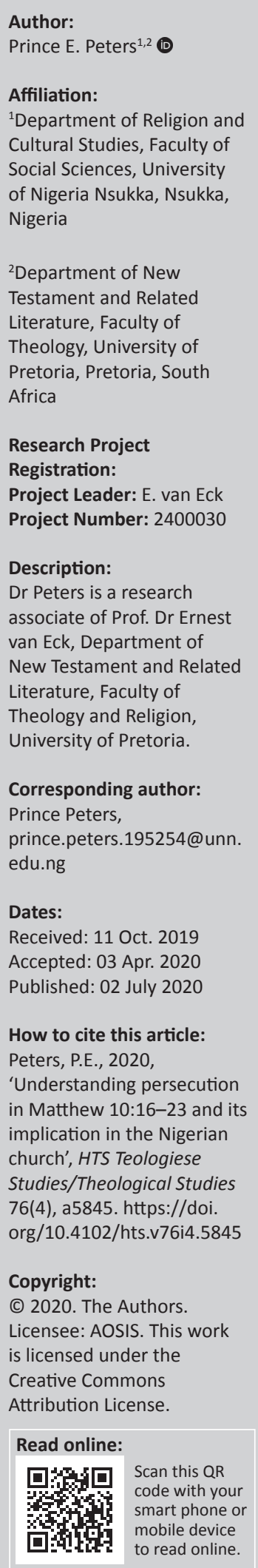

The modern use of the word 'persecution' in both speeches and books shows a phenomenon that is almost wholly associated with religion. However, persecution is a threat to the peace of religious institutions as well as various societies all over the world; thus, this makes it a phenomenon beyond the scope of religion. However, this research focuses on religious persecution. It studies an aspect of persecution which is called intra muros persecution. This means 'internal' persecution. 'Internal' in this context describes the kind that existed in the Jewish religious settings, amongst professing Jews, strictly between Rabbinic Jews and Messianic Jews as predicted in Matthew 10:16-23 and is reflected in today's Christianity in the form of various intra-denominational attacks in Nigeria. The study delves into the history of events which took place between Rabbinic Jews and Messianic Jews and how it relates to the Christian faith, coming out with the discovery that division which it called sectarianism was the brain behind this brand of persecution. The application of the study to the Nigerian situation necessitates the call for tolerance amongst various denominational sects in Nigeria.

Keywords: Persecution; Intra muros; Messianic Jews; Rabbinic Jews; Matthew.

\section{Introduction}

The Matthean community was distinctively set out from the rest of the Christian Messianic movements that existed in the 1st century because of some unique qualities possessed by it. This community was the only Christian Messianic group that emerged from core Jewish background and tried very hard to define its identity within the broader Jewish commonwealth even after the resurrection of Christ. ${ }^{1}$ Also, it was the community that faced much of persecutions from within by gentile Christians and without by both Rabbinic and Hellenistic Jews. Achtemeier (ed. 1985:613) reports that 'the church of Matthew was resident in a prosperous, urban, Greek-speaking area and subject to persecution from the side of a seemingly large population of both Jews and gentiles'. To be clear on these issues, a detailed and rigorous study was necessary on the background of the Matthean community and its attacks.

There is almost no certainty about the geographical location and setting of the Matthean community; however, it must be a Jewish community which shares a relationship with the gentile world in passing. ${ }^{2}$ The only probable relations they shared with the gentiles were the occasions of invitation made by the Rabbinic Jews to the gentiles, namely the Romans, to help deal with various religious and politically motivated affronts, including the unrest from Christian Messianic Jews. ${ }^{3}$ This Jewishgentile relationship got to its zenith and led to the fall of Jerusalem and the temple in it, which Rutishauser (2014:3) described as 'the scene of liturgical and propitiatoryrites'. The fall of Jerusalem arguably brought about an almost extermination of the Jewish race as reported in Josephus' (1987:727) Wars. Josephus (1987) sadly recounted that 'they had their right hands already polluted with the murders of their own countrymen, and in that condition ran out to fight with foreigners' ${ }^{4}$

1.Viljoen (2016:1) states that 'the Matthean group was still in a process of establishing its own identity as deviant Judaistic group' whose specific interest resided in the meaning and interpretation of the Jewish law (Viljoen 2012:255), whilst Oliver (2016:367) informs that the Matthean community's text is referred by Harrington (2013:159) 'as the most “Jewish" of the gospels'.

2.Vledder and Van Aarde (1995:388-408) present various hypotheses favouring Antioch as the geographical location of the Matthean community and other hypotheses opposing such ideas, which make the certainty of Antioch or any other geographical city for the Matthean community only a guess work.

3.The Jews masterminded a report sent to Emperor Claudius that the disciples of Jesus broke into Jesus' grave and stole his body whilst soldiers slept. This report by the Jews to the Roman emperor against the Christians must have led to a series of events culminating in raising Jerusalem to the ground. For further discussion, see Bruce (1962:309-326).

4.The Roman domination of Jews, starting with the Jewish invitation of Pompey during the Mithridatic wars, led to several revolts from some Jewish groups. We understand Josephus' haireseis (used for four of those groups) not to actually connote sectarianism but 'philosophy' (Baumgarten 2015:262). However, the fourth of those philosophical groups, the sicarii was Jewish, the so-called bandits distinct from Zealots and other bandits (see Horsley 1979:436; Vandenberghe 2016:2). Although they were considered bandits mainly

Note: Special collection entitled Africa Platform for NT Scholars, sub-edited by Ernest van Eck (UP). 
It is probable that Matthew's community existed in an intra muros situation with the rest of the Jews, although its intramural status is challenged by the debate of 'whether the Birkath ha-Minim ... has been established by the time Matthew writes' (cf. Carson 1982:161). ${ }^{5}$ Yet there are sufficient reasons to show that the Matthean persecution as predicted in chapter 10 was intra muros (see Carson 1982:161; Fraatz 2010:2; Stanton 1992:118-124), that is to say, the persecution came to Messianic Jews from Rabbinic Jews at the time when the Messianic Jews still saw themselves as part of the Jewish faith. ${ }^{6}$ The astuteness in such a belief stems from the fact that the contending parties were Jews in both beliefs and nationality at the time; this did not mean that they worshipped in the same synagogues (Mt 12:9) or agreed on the Halakah.

Carson (1982:161-162) has pointed out that some scholars oppose this stance by suggesting that the gospel community called 'Matthew represents a form of Jewish Christianity that has broken with Judaism but is still defining itself over against Judaism'.

Carson (1982) then concludes that the persecution, which he preferred to call 'struggle', was extramural. However, what this study considers extramural persecution is the attack meted on gentile Christians by both their countrymen and Jews afterwards for turning their backs on their various native religions and embracing an ideology which is neither Judaism nor paganism (cf. Fredriksen 2006:596-597). The argument in favour of the Matthean community as being part of the Judaistic faith at the time of its persecution is logically considered valid when one views their professing of Jesus as the Messiah in the presence of their Jewish brethren (e.g. Ac 4:10). That necessitated the Birkath ha-Minim. The persecution was carried out against the Matthean Jews, who by then were weak because they did not have the backing of the temple or the government of the day, not excluding that the theology of their quintessence, Christ, was considered isolated and unorthodox. At the time, they were thought of by the Romans to be a part of the Jewish religious world (Fatokun 1999:9), but seen by Rabbinic Jews as heretics because of their belief in the advent of Messiah (Waardenburg 2004:14). For a misunderstood assertion that they believed in and preached the advent of a 'false' Messiah, they were variously attacked but not excommunicated; however, they finally parted from mainline Judaism. The date of the parting has been described variously but the study would settle with '200 CE, when Jewish persecutions of gentile Christians and increasingly

\footnotetext{
by Josephus, their leadership was intelligentsia as descended from the sophistes Judas (Bellum Judaicum 2.118, 433; cf. the sophistai Matthias and Judas in 4 BCE, Bellum Judaicum 1.648; Antiquities 17.149). Their guerrilla warfare against Rome may have contributed to the destruction of Jerusalem and planting in its stead the
} Aelia Capitolina in $70 \mathrm{AD}$

5.Viljoen (2016:4) suggests that scholars traditionally dated the Birkath ha-Minim ca. 85 CE (e.g. France 1998:85; Horbury 1982:19-61). He insists that this date, however, is dubious. Viljoen goes on to state that 'the Birkath ha-Minim developed over period of time while synagogues at different locations and times increasingly did not period of time while synagogues at different locations and times increasingly did not It is also not clear how widespread the Birkath ha-Minim has been used'.

6.Viljoen (2016:4) tells us that 'Hummel (1966:55) has described the relationship of the church with Judaism as part of a larger "family conflict" or a rival among feindliche Brüder. It was not so much a conflict with the Christian community as an outsider group, but strife within Judaism' effective ecclesiastical organization combined both to articulate and to finalize the "inevitable" break' (Fredriksen 2003:35). This parting was 'the eventual result of mutual incomprehension and suspicion' (Stanton 1992:10).

As has been stated earlier, the Birkath ha-Minim was a promulgation to react to the Matthean community intra murosly. The Encyclopedia Judaica (2008:par. 3) states that it was formed and added to the Tefilat Ha Amidah [the standing prayer] as the 12th benediction in 'Eighteen Benedictions ${ }^{\prime 7}$ around $85 \mathrm{AD}$. This date is, however, questionable. Langer (2013) asserts the following:

The Birkath ha-Minim, according to rabbinic tradition, was added to the 'amidah' in the late 1st century CE in response to minim, some sort of sectarians. If not originally, then at least by the end of the fourth century, it explicitly named nozerim (Nazarenes or Christians) with these minim in some versions. (p. 8)

This move was to incriminate Messianic Jews and to bring God's curse on them by reciting three times daily the words 'God curse the Nazoreans' (Mayo 2006:331; Nadler 2012:2) in order to ostracize them from general synagogues. The words of the Birkath ha-Minim (France 1998) are as follows:

Let Nazarenes (Christians) and minim (heretics) perish in a moment, let them be blotted out of the book of the living, and let them not be written with the righteous. (p. 85)

Situating the text of the study in its pericope, it is found as the second discourse of Jesus, which has been recorded in the book of Matthew (Mitch \& Sri 2010:29). The whole chapter where the pericope resides is a conglomeration of the talks delivered by Jesus on a single motif: persecution. The talks were delivered at different times and places, to which the Matthean School redacted to suit one purpose. The purpose was to explain that even Christ himself believed that persecution was expected for all his disciples in all ages (Cochran 2014:9-10). Christ's simple prescription against this traumatic situation was his enlightenment speech to his disciples, asking them to be as wise as serpent and as harmless as dove. Christ's popular comparative phraseology of sheep and wolves represented the disciples of Christ, on the one hand, and Rabbinic Jews, on the other hand. ${ }^{8}$

These two Jewish parties survived two Jewish wars and entered into an era where they were permanently divided against each other on a straight part never again to become one.

The study of persecution in Matthew 10:16-23 King James Version (KJV) relates the danger faced by the Christian Messianic movement in the 1st century to the intradenominational Christian wars witnessed in Nigeria's Christianity today. In other words, Matthean intramural persecution forms a contextual background to understand

7. Langer (2012) informs us of Joseph Heinemann's school of thought interpreting include one on the topic of "separatists". She talks of Saul Lieberman, who suggest 1992). See also, more recently, Henschke (1999:90-96) cited in Langer (2012).

8.For an in-depth discussion on the subject, see Davies and Allison (1991:181). 
the intra-denominational persecutions going on today in Nigerian Christianity. It should be pointed out that the author agrees with Olojo's (2014) assertion that:

Muslim-Christian religious violence appear [sic] to gain more local and international traction in academic and media circles in contrast with the attention accorded to the narratives of intrareligious violence. (p. 3)

This accounts for low literature that discussed intramural persecutions in Nigerian churches. ${ }^{9}$

The article asserts that there are no more visible, widespread mutual attacks between Rabbinic Jews and Messianic Jews, but rather between factions in a denomination and also between various denominations of Christianity in Nigeria. The factional war in Assemblies of God church, Nigeria (herein after referred to as AGN), since 2014, serves as a case study. The author conducted an oral interview on the ousted general superintendent in which he spoke about the remote and immediate causes. The study yielded to the finding that what instigates intramural attacks concerns, amongst other things, doctrines, and these attacks, which present themselves as both verbal and psychological, are the physical ways to show-off unalloyed and unflinching doggedness in Christian orthodoxy and doctrinal purity. These attacks naturally produce retaliatory actions to the extent of tearing asunder the seamless coat of Christ, all in a selfish defence of orthodoxy. However, the problem statement of the study goes beyond physical and psychological attacks targeted at rival denominations to include a subtle conveyance of the idea of superiority and orthodoxy by the persecutor to the persecuted. Such conveyance features regularly in church Bible studies, homilies and scholarly discussions on electronic, social and print media.

This study's objective is to find remote and immediate causes of intra-denominational attacks in Nigerian churches, especially as it exists in AGN today, and to proffer a sound academic solution. Textual, form and historical critical methods were used to systematically align the study with the best practices of biblical studies, and Kieh's (2002:12-13) eclectic theory, as modified by Akanji (2011:65) for the purpose of religious conflict management, was employed to study the multi-dimensional aspects of conflict in Nigeria. This latter theory was re-modified to interpret conflict situations within the Christian denominations in Nigeria.

Social scientific criticism was also used to interpret the historical world behind the text, rather than the historical world in the text (Wendland 2017:40). Consequently, the study robustly contributes to the growing body of literature, which fights denominational superiority in the guise of upholding sound doctrines amongst various denominations in Nigeria.

\section{Text of Matthew 10:16-23}

In this section, the author proceeds to do a verse-by-verse exegetical analysis of the study text. Application of exegesis to the intramural situation in Nigerian church follows immediately.

9.A good book discussing intramural persecutions, which it called "conflict', was Augsburger's (1992) book.

\section{Verse 16: Apostolic enlightenment regarding

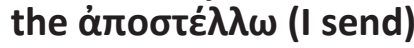

Jesus' use of language in the pericope under study is enigmatic. He uses popular terms in quite a spiritual manner,

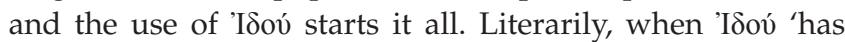
an acute accent ... it is used as a demonstrative particle to draw our attention to something' (Revised English Version Commentary 2019:13). Leim (2014:87) refers to it as 'the attention-grabbing particle' and it carries the same import in this passage. It seems that Jesus used it to call attention to his statement (Hagner 1993:276) as if he said, 'look', 'listen, pay attention to this all important announcement'. The attention the great $\alpha \dot{v} \theta \dot{\varepsilon} v \tau \eta \zeta$ [master] and $\dot{\varepsilon} \kappa \pi \alpha 1 \delta \varepsilon v \tau \eta \dot{s}$ [instructor] sought from his $\mu \alpha \theta \eta \tau \alpha i ̀$ [disciples] was not to merely listen but to bring their entire mind into what he had to say.

Pinar (2015:1306) provides a strategy for bringing the attention of students to the teacher, which he called fixed-time (FT) schedule. 'FT schedule involves the delivery of a stimulus, independent of behavior after a set period of time has elapsed' (Pinar 2015:1306). This social scientific tool is just comparable to Jesus' use of 'Iסov́, which presupposes the application of a rabbinic pedagogic technique in the middle of his sayings. This becomes obvious in the infusion of apocalyptic urgency in his pedagogy, which is the falling out of the Jews with the Jesus' people - Messianists; this results in intra muros persecutions. Jesus' position as a Jewish teacher has been never in doubt. In fact, '[f]ar from being some illegitimate self-appointed wanderer, Jesus was recognized by his rabbinic competitors as a teacher', even though 'the Pharasaic order may have disagreed with Jesus' midrash

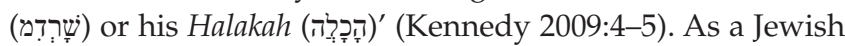
rabbi, Jesus displayed the knowledge of FT schedule in Matthew 10:16, which was also applied in the Shema Yisrael [Hear O Israel] dogmatic recitation. Urkin et al. (2017:5) made a comparative table of traditional Jewish and modern teaching techniques. Under the Jewish teaching techniques, '[c]onsideration of the student's needs and abilities in pacing study' was mentioned. This parallels with '[s]tudent-centered teaching; personal learning plan and portfolio' under modern teaching techniques; this is a good example of FT schedule in ancient Jewish pedagogy. Furthermore, it should be borne in mind that Jesus' use of 'Ioov́ never displays narcissistic tendencies. Some people who use various vices to seek attention may be suffering from a psychological disorder known as histrionic personality disorder (Lewis \& Mastico 2017:1).

Jesus is, however, absorbed of this psychological challenge because there is nothing in 'I $\delta$ ov that suggests a desperate attention-seeking. In fact, on the contrary, the use of such a strong gesture as 'I $\delta$ ov suggests the imminence of the warning he gave to which he wanted them to be both wary of and alert.

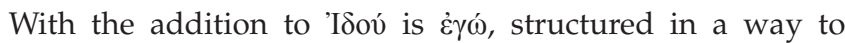
strengthen emphasis. 'E $\gamma \omega$ ' on its own, as it appears in this passage, may be considered as one of those 'I am statements' 
outside the book of John, and with no predicate used to concretise his divine person. Although in the book of John, Jesus used the I am statements to answer numerous questions that arose about his person, questions such as 'who is Jesus?', 'who are you?' and 'who is he that I might believe in him?' (Vereş 2008:111), but in Matthew he uses it to take

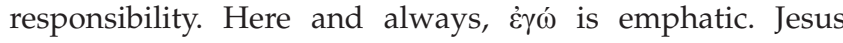
would have said by the use of that pronoun, 'it is I who (am) that send you into the midst of such dangers; conduct yourselves, then, in such circumstances in a manner becoming those who are my messengers'. The emphasis on ' $\mathrm{I}$ ', as stated earlier, explains that the sender takes responsibility for anything that proceeds from the sending and so, relaxes any worry that should accumulate from the disturbing situations associated with the sending. But the sending $(\dot{\alpha} \pi \circ \sigma \tau \varepsilon \dot{\varepsilon} \lambda \lambda \omega)$ without an assurance of protection leaves room for serious worry when the comparison of the caliber of messengers he sends is made with the kind of creatures he is sending them to.

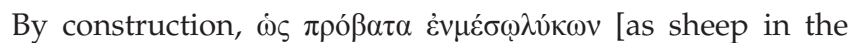
midst of wolves], Christ projects the idea of danger (persecution) inherent in his mission mandate. However, the text arouses curiosity about the antagonistic relations that exist between sheep and wolf, of which the sheep is made a prey for the wolf.

Furthermore, the prey is asked to utilise a particular instrument in his effort to safeguard himself from the predator. The instrument is 'prudence', a word quite imbued with meanings from its Greek etymology. When $\varphi \rho$ óvuo interprets prudence, it carries with it the implication of practical wisdom and sensibility. Christ's call for prudence should be seen from the subtlety of acts associated with religious persecution itself. This calls to the mind that the act of religious persecution is more complex than acknowledged popularly. For example, coercion in itself is widely known as persecution, but Gunn (2002:22) goes a step further to see coercion as being much more than what is described popularly. He identifies two directions that coercion can take in a religious persecution, namely, 'coercion that attacks or interferes with religion' and 'coercion that enforces religious conformity'. The first is the popularly known type of coercion in religious persecution. Gunn (2002:22) defined it as that which is 'against a religious believer, a religious community, or a group of religious communities'. He further insists that (Gunn (2002):

[T] he coercion may consist of attempts to disrupt religious services, cause harm to religious buildings, shrines, and symbols, or to threaten the lives of others. The actions may be taken for the purpose of expressing hatred or of destroying a religious community or of forcing it to flee. (p. 22)

The second kind of coercion described by Gunn (2002) is:

$[T]$ hat of enforcing religious conformity on a community. In such situations the state or a religious community uses compulsion to require members of a religious community to comply with religious (or cultural) rules. (p. 22)
This second kind of persecution is largely overlooked and misunderstood, and the kind of persecution this study attends to discuss.

\section{Verses 17-18: Psychosomatic attacks in defence of Christian orthodoxy}

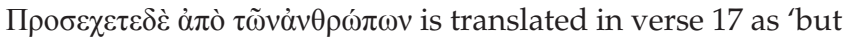
beware of men'. Jesus' figurative use of wolves and sheep is present in this verse, straightened by the mention of real predators: men. Jesus' idea of men in the text is somewhat beyond superficial description. On matters that relate to religion, man can unleash the most dangerous mayhem on his fellow man as undeniably borne in the history. Man easily finds justifiable reasons to feed on his fellow man so far as religion is concerned. On the platform of religion, man's common thought pattern when he meets another man of smaller strength is, 'a wolf does nothing wrong in killing sheep for food, so why should it be wrong for human beings to eat meat?' (Fink 2005:1). With this insatiable carnivoracity that exists in man's depraved mind, punitive laws are always enacted to make anyone who eschews violence for religious sake a ready prey. Such laws and its execution would even be

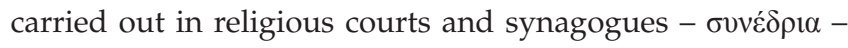

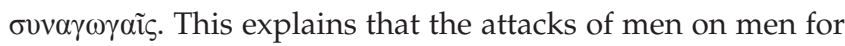
religious reasons would never happen outside religious institutions but carried out right in the midst of religious

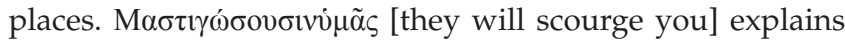
that religious persecutions can graduate from being psychological to being psycho-physical. 'They will scourge you' in their councils, and synagogues could be interpreted to mean that people would rise in arms against others for religious reasons. Gunn (2002:33) has sadly admitted a truth that a Christian churchman or even a denomination would actually rise up in arms against another Christian denomination. He reminded us that 'defrocked Orthodox priest Vassili Mkalashvili in Georgia has led attacks on religious services of non-Orthodox churches'.

Christ's prediction of the places where his disciples shall appear in order to be judged for the sake of their faith surprisingly moves outside the Jewish temple and synagogues to include government houses presided by kings and governors. Tertullian understood the persecution recorded in this text and Jesus' subsequent instruction to flee from one city to another as limited to both the Jewish lands and the original disciples, ${ }^{10}$ probably because of the

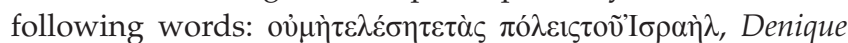
Non consummabitis, inquit, ciuitates Israelis ['you shall not have gone over the cities of Israel']. But the involvement of

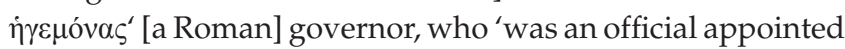
to be the chief administrator of Roman law in a province, and included military and administrative duties' (Graves 2017:74) contradicted Tertullian's proposition. i่ $\gamma \mu$ óvas explains the position that Pontius Pilate occupied in Roman Judea in those days, to whose presence Christ was brought and before whom Christ was condemned. However, such governors 10.Tertullian, De Fuga 9. 18. 
were not found only in Judeanor did they operate only within the period of the apostles. ${ }^{11}$

Furthermore, it is doubtful whether the kings mentioned afterwards included any Roman ruler because the rulership of Rome in the 1st century was under an emperor. However, the use of plural $\beta \alpha \sigma \lambda \lambda \varepsilon i \varsigma_{\zeta}$ naturally expands the geographical horizon of apostles' persecution beyond Israel. Also, it is now known that even before the republic, Rome was ruled by kings, starting with Romulus and ending with Tarquinius Superbus during 753-509 BC (Fagan 1999:16). The regal period ended and the republic started consequent of coup d'état to stop Superbus' son Sextus from ruling because the boy was a bad leader like his father, and even a rapist (Fagan 1999:20). But the Roman system of government at the time of Christ was the imperial system headed by Tiberius, decades after 'Octavian gradually arranged the state on a new footing and placed himself at its head' (Fagan 1999:101).

\section{Verse 21: Family betrayal}

One of the most shocking experiences that people go through is betrayal, especially by those whom they trusted and least expected the betrayal from them. 'Betrayal has been predicted to have a significant impact on cognitions (e.g. negative attributions for perpetrator's behavior), affect (e.g. sadness) and behavior (e.g. demands for retribution)' (Gobin 2012:22).

Religion as opium has the potentialities to induce a trusted ally to betrayal, which creates traumas that are commonly 'associated with greater symptom severity across various mental health outcomes, including depression, anxiety, posttraumatic stress, and hallucinations' (Martin, Ryzin \& Dishion 2016:2).

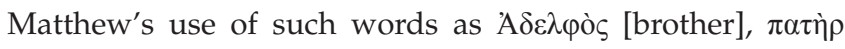

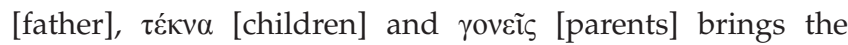
emotions of family bond to bear, but religious divergent opinions are powerful enough to force people to break such

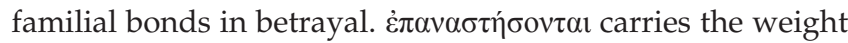
of physical attack which could even be extended to $\theta \alpha v \alpha \tau$ ó $\omega$ [murdering or causing the murder] of one's family member because of disagreeable religious opinions. From the exegesis of Jesus' words, it is seen that religiously motivated forces could lead people to homicide, even though Dietz (1986:479) refused to admit this. The pericope of the study was an eyeopening fact that intimidated and persecuted would not be victimised by people of superior intelligence. It is also suggestive that the attacker has much of connections with the attacked, mainly biological, making the attacker very weak to retaliate. This could be seen in cases where the father would attack a son or a son attacking the father. This type of

11.In fact, Roman governors were in charge of Roman provinces even at the time of Tertullian and he even wrote about them (Tertullian, Apol. 30.5-7: CCL 1, 141-142.). Far from the 1st century when apostles operated, Tertullian was said to have written 'at the turn of the 3rd century CE' pointing 'out Pliny's hesitation to sentence the Christians and takes issue with Trajan's reply' (Carlson 2012:36) Part of the letter states, Tunc Traianusrescripsit hoc genus inquirendosquidem non esse, oblatosveropunirioportere. O sententiam necessitate confusam Negatinquirendosutinnocentes, et mandate puniendosutnocentes (Tertullian, Apo 2.7-8). It is interesting to note that this Pliny who hesitated to punish Christians was Tertullian's contemporary and he was a Roman governor. persecution produces some form of emotionalism because of what holds the persecutor and the persecuted together and for this emotional situation, and not because of fear, Christ admonishes the persecuted to flee. The advice to flee from a persecutor was never given to those who are facing extermination and annihilation in the hands of strange government and rival religions; it is only applicable to intrareligious crisis. To what a believer or a believing community should do when the attack is extra-muros? The answer to this question seems to be found in Luke 22:36 KJV. Cases of genocide (such as the case of Hitler's Second World War) or terrorist insurgencies (such as the ravaging Fulani herdsmen in Nigeria) should not be treated in the pericope under study because it fits a rather different context.

\section{Verse 23: Certainty of persecution and attacks}

The warning of imminent persecution in the text carries with it the dual idea of certainty and preparedness against it by the employment of the conjunction ö $\tau v$ and the adversative particle $\delta \dot{\varepsilon}$. Such note of preparedness also conveys a soothing idea of comfort (https://biblehub.com/commentaries/egt/ matthew/10.htm). These twin conjunctions suit a situation if one is sure of an event to occur but has no idea when it would take place. Therefore, when they persecute you here

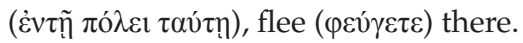

\section{Summary of Exegesis}

The result of exegesis proved that from the foregoing Christ took responsibility of exposing his disciples to the various forms of possible attacks following the mission mandate he gave them. However, he warns that certain individuals who could be used to constitute obstacles (in the form of persecution) to the mission would not be strangers to the persecuted, rather they would be well acquainted with them. He sets out the boundary of attacks, which would be 'for the sake of his name'. He, however, advised that as the persecution is certain, the disciples have the option of moving from one city to another, avoiding the persecutor carrying along, as it were, the gospel message that he has entrusted to them. The exegesis was applied to the Nigerian church, where it has become fashionable for the church to split into factions and one faction would rise, sometimes violently, against the other. The exegesis targeted the lacuna of scholars' neglect of internal church crisis as a form of persecution. Whilst it made efforts to close this gap, it provided a solution in its non-retaliatory campaign so far as intramural persecution is concerned.

\section{Solving textual problems in Matthew 10:23}

In verse 23 of the pericope, there was a textual problem.

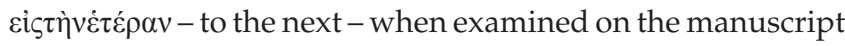
and date support, the reading of $\dot{\varepsilon} \tau \dot{\varepsilon} \rho \alpha v$, which is supported by $\kappa$ and $B$, is preferred to $\alpha \lambda \lambda \eta v$ in all their various readings. An argument from the theological interest of Matthew's gospel, which is succinctly captured by Utley (2013:11), would however project evangelism and discipleship as the 
heart of Matthew's gospel. If this argument is to be adopted, then Matthew's original word in the passage could be ó $\lambda \lambda$ os [another of a different sort] to refer to gentile cities, and under circumstances $\dot{\varepsilon} \tau \dot{\varepsilon} \rho o s$ would not apply because $\dot{\varepsilon} \tau \dot{\varepsilon} \rho o s$ is suitable only in an explanation that justifies fleeing from one 'Israelite' city to another 'Israelite' city. Utley (2013:11) reminds us that the gospel mandate of Christ, especially as contained in the persecution motif of Matthew 10, is universal and not particular; this would properly embrace

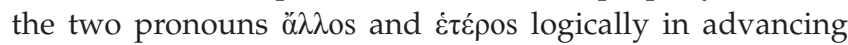
evangelism.

\section{Adopting a reading}

Utley's (2013) theological interest may not give a right understanding of the textual problem because it does not take care of the statement that '[y]ou will not finish going through the cities of Israel, until the Son of Man comes' (Mt 10:23). This statement is regarded by Stewart (1997:169) as 'one of the most difficult in all of Matthew' because scholars are not fully aware of what Jesus meant there. This in fact helps to worsen the sought-after solution to the textual problem because the text's both figurative and literal positions fit into any of the textual variants. The study therefore reconstructs the problem passage based on careful examination of all variables and readings in the passage. Consequently, it argues that the original text should read: ' $[b]$ ut when they shall persecute you in this city, flee ye into another ( $\alpha \lambda \lambda$ os); and if they persecute in the other, flee ye

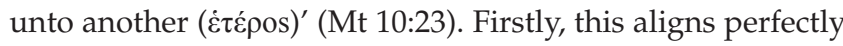
with the second variant and reading, which justifies the use of both pronouns. However, the research noticed that the second variant is scarcely supported by quality manuscripts. It could lead to doubts about the authenticity of accepting the reading if not that the first reading, which boasts of texts in the Alexandrian family as well, lays credence to the validity of the second variant. This, therefore, authenticates it. In conclusion, some Apostolic and Church fathers such as Clement, Origen and Cyprian supported the idea of fleeing during persecution (Sutcliffe 2018:135); however, their argument for the acceptance of flight during persecution has nothing to do with evangelism amongst gentiles, and so do not encroach into the reconstruction given to the passage.

\section{Sitz im Leben of persecution in Matthew 10:16-23}

The sitz im Leben of Matthew 10:16-23 properly situates on the internal attacks by Rabbinic Jews on Messianic Jews. It is an eye-opener to the acrimonious hatred suffered by Messianic Jews. The Old Testament scriptures talked about the birth of a Messiah (the anointed one) who would rule Israel (see Mi 5:2ff. KJV) after rescuing it from the hands of gentile overlords who have made them wander in sins - ipse enimsalvumfaciet populum suum a peccatiseorum - for he shall save his people out of their sins (Mt 1:21). At the emergence of Jesus, some Jews who were well versed in Judahite prophetic texts understood and so believed that he was the ruler that the Old Testament prophets severally talked about, ${ }^{12}$ even though the popular Jewish understanding before the inter-testamental period was that the Messiah must be a warrior like the ancient King David, limited in operation to the Jewish race..$^{13}$ Therefore, when he came as a controversial teacher and not as a warrior, some Jewish sects needed clarity on who was he, or else they would not accept his claim as the Messiah (Mt 26:63).

Because Jesus never met the proper qualifications of a messianic candidate (Mishkin 2015:1), the very thought of he being the Messiah was blasphemy to some sections of Jews, and the blasphemer deserved death. This was the major cause of persecution that Messianic Jews received, of which the direct consequences included the separation of Matthean community as the new People of God as distinct from the nation which rejected Jesus as their Messiah' (Viljoen 2006:para. 1). The sitz im leben of Matthew's gospel makes for the argument that the actual date of writing the gospel should not be placed after the 70 AD Roman invasion; to do this would present a narrative that is anachronistic and far removed from reality. Instone-Brewer (2003:2) lays credence to this idea by citing Heinemann, who believed that the main development of the prayer (Birkath ha-Minim) took place before $70 \mathrm{CE}$; and as the gospels are reactions to the promulgation of the Birkath ha-Minim (Carson 1982:para. 1), a later date would be problematic. ${ }^{14}$ Kilpatrick (1946) agrees with this.

\section{Physico-mental persecutions amongst Nigerian churches}

The use of Gunn's (2002:22) framework is further maintained in this exegetical application. He refers to the study's type of persecution as 'Coercion that enforces religious conformity'. It is, therefore, intra muros. However, a brief overview of extramural persecution in Nigeria is necessary for a proper appreciation of the trauma faced by Nigerian Christians, which unarguably has much of adverse effects on their psychosomatic health. Lives of many Christians in Nigeria have been wasted by Islamic extremists, most recently by Fulani herdsmen and the Boko Haram sect, which has been dubbed as 'the world's deadliest terrorist group in terms of the number of people it has killed' (Baba 2016:59). This is an oppression meted out to the Christians who number about 86.5 million, that is, $46.3 \%$ of the total Nigerian population (ed. Grim et al. 2017:83). The size of Christians in Nigeria makes them a deadly weapon if their religion had expressly permitted them to fight back.

Going back to intra muros persecution, the research considers it as the most disturbing type of abuse because it is the

12.That the eschatological ruler would be a restoration after the Davidic rule had been cut off is apparently suggested by pre-exilic prophets (Jesse's 'stump' in Isa 11:1; cf. perhaps David's fallen tent [as opposed to 'house'] in Amos 9:11, although scholars debate passage's meaning and date). - see Keener (2015), Messianic Expectation Prepared for the Yale Centre for Faith and Culture Consultation on 'expectation and human flourishing', p. 1

13.After the devastation of 66-73 CE, some leading rabbis hailed a messianic figure in the early 2 nd century (during the Bar Kochba Revolt of 132-135 CE). This revolt's failure led to messianic disillusionment in the early rabbinic sources, but eventually messianism surrounding the promised Son of David revived - Keener ('1), Messianic Expectation, p. 2.

14.For more discussion on the evidences for an early date in the composition of the book of Matthew, see Stewart (1997:13-14). 
persecution within the same body. The same pattern of persecution features in Nigerian Christianity, where various denominations show the strength of human muscles against one another just to display superiority or to defend Christian orthodoxy. Lay people who have been severally brainwashed are used by some denominations to carry out these nefarious activities against brother denominations. Although it is alleged that 'congregations do not enjoy conflict' (Oppenshaw, Nel \& Louw 2018:3), these congregants are the ready instruments of conflict and attack (Ellis 1989:244; Haynes 2009; Otite \& Ogionwo 2006). Such thuggery is made possible because, according to Lenshie and Inalegwu (2014), religion has turned into:

[A] force which has packaged the thought pattern of most Nigerians not to think outside what they believe in, and anything that appears to contradict their belief systems, they tend to oppose it vehemently, which consequently has been a major source of conflict among various religious adherents. (p. 47)

The events of Matthew 10:16-23 reflect an internal war because of divergent doctrinal opinions between people who shared religious and biological kinship. This also reflects in the history of the church, where after classical martyrdom and subsequent 1000 years of general peace, the church that was delivered from this persecution has turned around to persecute itself. This behaviour spurred some individuals towards a return to the New Testament faith without embellishment and the paraphernalia of Roman and Greek mystical religions. Such a call for return to Christian orthodoxy further led to more unwarranted killings of so many Christians in the medieval era in the form of crusade and inquisition. ${ }^{15}$ The church finally broke loose from the stifling grip of Graeco-Roman patrimonial Christianity during the Reformation. Such liberation produced Pentecostal churches, which would have set a clean example, correcting the mistakes of the medieval church. However, it seems the world expected too much from the reformers and their descendants. Assemblies of God Church, Nigeria poses as the mother of Pentecostalism in Nigeria, and such a claim has been backed by a solid history. The researcher happens to possess first-hand information about the history of AGN from one of its founding fathers, late Papa George Nnorom Alioha. The story of Papa Alioha perfectly agrees with the research of Mbamalu (2016), which makes Mbamalu's history impeccable. Assemblies of God Church, Nigeria was started by Pa Ehurie Nwogu after he was born again in 1930 and converted a few of his kinsmen, including Papa Alioha. They formed a congregation called 'the Church of Jesus Christ' (Mbamalu 2016:1). These men, who were young in both age and faith, needed the mentorship of stronger born-again Christians, but unfortunately, at that time such 'stronger' people were living abroad. Through contacts in numerous gospel tracts published by the Assemblies of God, USA, which was also the channel of their Holy Ghost baptism, they

15.Jones (1998:9) mentions that the Albigensian Crusade directly led to the establishment of first inquisition, which on 22 July 1209 saw the slaughter of over 20000 men, women and children from the city of Beziers. Stark (2016:9-10) considers the crusades as promoted 'by power-mad popes' seeking to greatly expand Christianity ... and thus the crusades constitute 'a black stain on the histor
of the Catholic Church' - from Ekelund (1996). Quotes from Madden (2002). invited white men, who arrived Old Umuahia, to mentor and incorporate the Church of Jesus Christ, thoroughly populated by the Igbo men into AGN.

Following this, Mbamalu (2016:3) sees the crisis in AGN as foundational for both leadership and ethnic dominance, and at the same time faults their Presbyterian leadership style because of its poor hierarchical structure.

Edike's (2014) newspaper interview, which was granted by the ousted general superintendent of AGN, Rev. Paul Emeka, was targeted at clearing the air on the allegations against the general superintendent which were also mentioned in Mbamalu (2016:6). These allegations were immediate causes of the crisis, finally leading to the untimely removal of Rev. Emeka. However, both Mbamalu (2016) and Edike (2014) did not represent the causes of problems very well. The oral interview conducted with the ousted general superintendent produces remote and immediate causes of crisis. About the remote cause(s), he said (Edike 2014):

Assemblies of God began to get lax and began to think of herself as the most spiritual and holiest church in the whole world. And for that reason was no longer careful over so many things until certain criminal and immoral acts began to creep into the church. (n.p.).

'Criminal and immoral acts' could be understood as the pursuit of dogmatic accurateness at the expense of sound religiosity. Still on remote causes, he mentioned people's freedom to embezzle money, high-handedness, poor handling of ministers' transfers and funds, etcetera. On immediate causes, Rev. Emeka charged ambassadors (a group of elite members in AGN) of accusing him with many unprintable falsehoods, which were not substantiated. The public belief in such allegations led to the crisis in AGN.

The researcher understands that the remote causes leading to AGN crisis happened or started happening during the tenure of the past general superintendent, and merely spilled over during the administration of Rev. Emeka. The study also understood that the ambassadors who were instituted by the past general superintendent were his puppets. Finally, the study also realised that the past general superintendent had a choice candidate over Rev. Emeka, but that candidate failed to win the position in a free and fair election. This led to instigations using the ambassadors to oust and replace Rev. Emeka. In short, the past general superintendent had an unbreakable influence on church to both make and destroy it. Meanwhile, most of the allegations levied on Rev. Emeka, and which led to years of bloodbath, have not been substantiated by any academic scholarship because the case is still in the court. Again, this paper opines that the AGN did not exercise enough patience and maturity to allow the ousted general superintendent to complete his tenure. One wonders why the AGN did not put late Rev. John Nwakamma through such a humiliation as they did with Rev. Paul Emeka when Nwakamma used the power of incumbency to amend 'the 
bye-law provision that granted a maximum mandate of four years in office' to general superintendent. He decided that any occupant of the office of general superintendent could remain there 'as long as the Lord wills' (Mbamalu 2016:5). Nwakamma's act was both criminal and ungodly.

\section{Summary}

Intra-church persecution of Christ, which is of the kind meted out to Messianic Jews by Rabbinic Jews, has been addressed as the brain behind the volumes of segregation, denominational proliferation and dogmatic incoherence found in the church today. It is the agent of irreconcilable differences paraded by various denominations against each other, and one of the reasons as to why rival religions do not find Christianity as a credible religion. Efforts were made to point out the excesses of the medieval Church through various forces, including inquisition, to make the body of Christ as one. Such moves were against Christ's own method, which was prayer (Jn 17:21). Adding to this, the Christian denominations, with AGN as a case study, have been deeply involved in internal crises and infightings, which are a type of persecution discussed in the study. The study of texts created an eye-opening experience to the fact that Christ does not want any form of violence or retaliation when the persecution is intra muros; rather, he advised for subtle means to manage such critical situations.

\section{Acknowledgements Competing interests}

The author declares that they have no financial or personal relationships that may have inappropriately influenced them in writing this article.

\section{Author's contributions}

P.E.P. is the sole author of this research article.

\section{Ethical considerations}

This article followed all ethical standards for a research without direct contact with human or animal subjects.

\section{Funding information}

This research received no specific grant from any funding agency in the public, commercial or not-for-profit sectors.

\section{Data availability statement}

Data sharing is not applicable to this article as no new data were created or analysed in this study.

\section{Disclaimer}

The views and opinions expressed in this article are those of the author and do not necessarily reflect the official policy or position of any affiliated agency of the author.

\section{References}

Achtemeier, P.J. (ed.), 1985, Harper's Bible Dictionary, HarperCollins, New York, NY.

Akanji, I.A., 2011, 'Towards a theology of conflict transformation: A study of religious conflict in contemporary Nigerian society', PhD thesis, School of Divinity, University of Edinburgh.

Augsburger, D.W., 1992, Conflict mediation across cultures, pathways and patterns, Westminster John Knox Press, Louisville, KY.

Baba, I., 2016, 'Analysis of cause and effect of Boko Haram Insurgency in North-East Nigeria', Journal of Faculty of Graduate Studies 5.

Baumgarten, A.I., 2015, 'Josephus and the Jewish Sects', in H.H. Chapman \& Z. Rogers (eds.), A companion to Josephus, pp. 261-272, Wiley and Sons, London.

Bruce, F.F., 1962, 'Christianity under Claudius', Bulletin of the John Rylands Library 44, 309-326.

Carlson, J.R., 2012, 'The gods and governers of the Roman provinces', PhD thesis, Department of Classics, Harvard University.

Carson, D.A., 1982, 'The Jewish leaders in Matthew's Gospel: A reappraisal', Journal of the Evangelical Theological Society 25(2), 161-174.

Cochran, G.C., 2014, 'Christian persecution as explained by Jesus (Matthew 5:10-12)', SBJT 18(1), 7-32.

Davies, W.D. \& Allison, D. Jr., 1991, A critical and exegetical commentary on the Gospel according to Saint Matthew, T\&T Clark, Edinburgh.

Dietz, P.E., 1986, 'Mass, serial and sensational homicides', Bulletin of the New York Academy of Medicine 62(5), 477-491.

Edike, T., 2014, 'Trouble in assemblies of God', Vanguard, viewed 16 June 2019, from https://www.vanguardngr.com/2014/04/trouble-assemblies-god/.

Ekelund, R.B., 1996, Sacred trust: The medieval church as an economic firm, Oxford University Press, New York, NY.

Ellis, S., 1989, The mask of anarchy: The destruction of Liberia and religious dimension of an African civil war, Hurst and Company, London.

Encyclopedia Judaica, 2008, Birkath ha-Minim, viewed 25 November 2017, from https://www.jewishvirtuallibrary.org/birkat-ha-minim.

Fagan, G.G., 1999, The history of ancient Rome, The Great Courses, Fairfax, VA.

Fatokun, S.A., 1999, History and doctrine of the early church, Enicrownfit Publishers, lbadan.

Fink, C.K., 2005, 'The predation argument', Between the species 13(5), 1-15.

Fraatz, T.C., 2010, 'Social conflict theory and Matthew's polemic against the pharisees', paper presented at the Ancient Borderlands International Graduate Student conference, University of California, 16-18th April.

France, R.T., 1998, Matthew, evangelist and teacher: Volume 1 of New Testament profiles, reprint, Intervarsity Press, Downers Grove, IL.

Fredriksen, P., 2003, 'What, "Parting of the ways?"', in A.H. Becker \& A.Y. Reed (eds.), The ways that never parted, pp. 35-64, Mohr Siebeck, Tübingen.

Fredriksen, P., 2006, 'Christians in the Roman Empire in the first three centuries AD', in D. Potter (ed.), Companion to the Roman Empire, pp. 587-606. Blackwell, Oxford.

Gobin, R.L., 2012, 'Trauma, trust and betrayal awareness', PhD thesis, Department of Psychology, University of Oregon.

Graves, D.E., 2017, 'Fresh light on the governors of Judea', Bible and Spade 30(3), 74-84.

Grim, B.J., Johnson, T.M., Skirbekk, V. \& Zurlo G.A., (eds.), 2017, Yearbook of international religious demography 2017, Brill, Leiden.

Gunn, T.J., 2002, The complexity of religion in determining refugee status, Emory University, Atlanta, GA.

Hagner, D., 1993, Matthew 1-13: Word biblical commentary, Word Books, Dallas, TX.

Harrington, D.J., 2013, 'Matthew's Christian-Jewish community', in D. Rudolph and J. Willitts (eds.), Introduction to Messianic Judaism: Its ecclesial context and biblical foundations, Zondervan, Grand Rapids, MI.

Haynes, J., 2009, 'Conflict, conflict resolution and peace building: The role of religion in Mozambique, Nigeria and Cambodia', Commonwealth and Comparative Politics 44(1), 52-75. https://doi.org/10.1080/14662040802659033

Henschke, D., 1999, 'Parashat Ha-lbbur and the blessing of the apostates [Hebrew]', in J. Tabory (ed.), From Qumran to Cairo: Studies in the history of prayer, pp. 3-29., Orhot, Jerusalem.

Horbury, W., 1982, 'The benediction of the minim and early Jewish Christian controversy', Journal of Theological Studies 33(1), 19-61. https://doi.org/10.1093/ jts/XXXIII.1.19

Horsley, R.A., 1979, 'The Sicarii: Ancient Jewish "terrorists"', The Journal of Religion 59(4), 435-458. https://doi.org/10.1086/486729

Hummel, R., 1966, Die auseinandersetzungzwischen kirche und Judentumim Matthäusevangelium, Kaisar, München.

Instone-Brewer, D., 2003, The eighteen benedictions and the minim before $70 \mathrm{CE}$, Tyndale House, Cambridge.

Jones, R.C., 1998, The crusades and the inquisition, a brief history, CreateSpace Independent Publishing Platform, Acworth, GA.

Josephus, F., 1987, The works of Josephus, transl. W. Whiston, Hendrickson Publishers, Peabody, MA.

Keener, C., 2015, 'Messianic Expectation', paper presented at the Yale Center for Faith \& Culture, McDonald Agape Foundation, June. 
Kennedy, J.S., 2009, Matthew's portrait of Jesus as Messianic sage, Academia.edu, San Francisco, CA

Kieh, G.K., 2002, 'Theories of conflict resolution', in G.K. Kieh \& I.R. Mukennge (eds.), Zones of conflict in Africa: Theories and cases, Praeger Publishers, Westport, CT.

Ki-FshuJah, T., 1992, A comprehensive commentary on the Tosefta, Jewish Theological Seminary of America, New York, NY.

Kilpatrick, G.D., 1946, The Origins of the Gospel according to St. Matthew, Clarendon, Oxford.

Langer, R., 2012, Cursing the Christians? A History of the Birkath ha-Minim, Oxford University Press, New York, NY.

Langer, R., 2013, 'The Zedah Laderekh's apologia for the Birkath Ha-minim', in A. Atzmon \& T. Shafir (eds.), Ke - Tavorbe-Harim, pp. 7-39, Studies in Rabbinic A. Atzmon \& T. Shatir (eds.), Ke - Tavorbe-Harim, prented to Joseph Tabory, New York, NY.

Leim, J.E., 2014, 'The father and the son: Matthew's theological grammar', PhD thesis, Divinity School, Duke University.

Lenshie, N.E. \& Inalegwu, S.A., 2014, 'Clash of religious civilisations in Nigeria: Understanding dynamics of religious violence', Research on Humanities and Social Sciences 4(17), 47-60.

Lewis, K.C. \& Mastico, E.R., 2017, 'Histrionic personality disorder', in V. Zeigler-Hill \& T.K. Shackelford (eds.), Encyclopedia of personality and individual differences, $\mathrm{pp}$ $1-9$, Springer, New York, NY.

Madden, T.F., 2002, 'The crusades in the checkout aisle,' crisis magazine, viewed 16 September 2019, from http://www.freerepublic.com/focus/news/798787/posts.

Martin, C.G., Ryzin M.J.V. \& Dishion, T.J., 2016, 'Profiles of childhood trauma: Betrayal, frequency, and psychological distress in late adolescence', Psychology Trauma 8(2), 206-213. https://doi.org/10.1037/tra0000095

Mayo, P.L., 2006, 'The role of the Birkath ha-Minimin in early Jewish-Christian relations: A re-examination of the evidence', Bulletin for Biblical Research 16(2), 325-343.

Mbamalu, W.O., 2016, 'Fellowship at orita: A critical analysis of the leadership crisis in the Assemblies of God, Nigeria', In die Skriflig 50(1), a2053. https://doi.org/ 10.4102/ids.v50i2.2039

Mishkin, D., 2015, 'The emerging Jewish views of the messiahship of Jesus and their bearing on the question of his resurrection', HTS Teologiese Studies/Theological Studies 71(1), Art. \#2881, 7 pages. https://doi.org/10.4102/hts.v71i1.2881

Mitch, C. \& Sri, E., 2010, The Gospel of Matthew, Baker Academy, Grand Rapids, MI.

Nadler, A., 2012, 'Do Jews curse Christians?', Jewish ideas daily, viewed 25 November 2017, from http://www.jewishideasdaily.com/4489/features/jews-curse-christians/.

Oliver, I.W., 2016, 'Messianic Jews and the early Jewish followers of Jesus', Hebrew Studies 57, 367-375. https://doi.org/10.1353/hbr.2016.0020

Olojo, A.E., 2014, Muslims, Christians and religious violence in Nigeria: patterns and mapping (June 2006 - May 2014), IFRA-Nigeria working papers series, no. 32 viewed 20 September 2019, from http://www.ifra-nigeria.org/publications/ e-papers/67-olojo-akinola-ejodame-2014-muslims-christians-and-religiousviolence-in-nigeria-patterns-and-mapping-june-2006-may-2014.
Oppenshaw, D.L., Nel, M. \& Louw, L., 2018, 'Conflict resolution and reconciliation within congregations', HTS Teologiese Studies/Theological Studies 74(2), a4641. https://doi.org/10.4102/hts.v74i2.4641

Otite, O.O. \& Ogionwo, W., 2006, An introduction to sociological studies, Heinemann Educational Books Limited, Ibadan.

Pinar, E.S., 2015, 'Effectiveness of time-based attention schedules on students in inclusive classrooms in Turkey', Educational Sciences: Theory \& Practice 15(5), 1306-1316.

Revised English Version Commentary, 2019, Matthew 1:20 commentary, viewed 09 June 2019, from https://www.revisedenglishversion.com/Matthew/chapter1/20.

Rutishauser, C.M., 2014, The Jewishness of Jesus: Renewing Christian appreciation, The Third Annual John Paul II Lecture in Christian-Jewish Relations, Boston College, Center for Christian-Jewish Learning, Boston, MA.

Saldarini, A.J., 1994, Matthew's Christian-Jewish community, University of Chicago, Chicago, IL.

Stanton, G.N., 1992, A Gospel for a new people: Studies in Matthew, T \& T Clark, Edinburgh.

Stark, R., 2016, 'The case for the Crusades', The Southern Baptist Journal of Theology 20(2), 9-28.

Stewart, D., 1997, Matthew, AusAmerica Publishers, Murrieta, CA.

Sutcliffe, R., 2018, 'To flee or not to flee? Matthew 10:23 and third century flight in persecution', Journal of Patrology and Critical Hagiography, Scrinium 14(1), 133-160. https://doi.org/10.1163/18177565-00141P10

Urkin, J., Fram, E., Jotkowitz, A. \& Naimer, S., 2017, 'Nurturing a society of learners: Suggestions from traditional Jewish pedagogy for medical education', Rambam Maimonides Medical Journal 8(3), e0033. https://doi.org/10.5041/RMMJ.10309

Utley, B., 2013, The first Christian primer: Matthew, viewed 26 May 2019, from http:// www.ibiblio.org/freebiblecommentary/pdf/EN/VOL01.pdf.

Vandenberghe, M.J., 2016, Villains called Sicarii: A commonplace for rhetorical vituperation in the texts of Flavius Josephus, Koninklijke Brill NV, Leiden.

Vereş, O.L., 2008, 'A study of the "I am" phrases in John's Gospel', Perichoresis 6(1).

Viljoen, F.P., 2006, 'The Matthean community according to the beginning of his Gospel', Acta Theologica 26(2), 242-262.

Viljoen, F.P., 2012, 'Matthew's sitzim leben and the emphasis on the Torah', Acta Theologica 32(2), 254-276. https://doi.org/10.4314/actat.v32i2.15

Viljoen, F., 2016, 'The Matthean community within a Jewish religious society', HTS Teologiese Studies/Theological Studies 72(4), a3418. https://doi.org/10.4102/hts. v72i 4.3418

Vledder, E-J. \& Van Aarde, A.G., 1995, 'The social location of the Matthean community', HTS 51(2), 388-408.

Waardenburg, J., 2004, 'Christians, Muslims, Jews, and their religions', CSIC and CMCU 15(1), 13-33. https://doi.org/10.1080/09596410310001631795

Wendland, E.R. (ed.), 2017, Interpreting the Bible: An overview of hermeneutics, Stellenbosch University, Stellenbosch. 